\title{
Aluminum Measurement
}

National Cancer Institute

\section{Source}

National Cancer Institute. Aluminum Measurement. NCI Thesaurus. Code C111127.

A measurement of aluminum present in a sample. 